\title{
Does Inflammation after Stroke Affect the Developing Brain Differently than Adult Brain?
}

\author{
Zinaida S. Vexler ${ }^{a}$ Midori A. Yenaria, b \\ a Department of Neurology, University of California, and b San Francisco Veterans Affairs Medical Center, \\ San Francisco, Calif., USA
}

\section{Key Words}

Stroke $\cdot$ Hypoxia-ischemia $\cdot$ Cytokine $\cdot$ Chemokine $\cdot$

Microglia $\cdot$ Neuroprotection $\cdot$ Neurogenesis

\begin{abstract}
The immature brain is prone to hypoxic-ischemic encephalopathy and stroke. The incidence of arterial stroke in newborns is similar to that in the elderly. However, the pathogenesis of ischemic brain injury is profoundly affected by age at the time of the insult. Necrosis is a dominant type of neuronal cell death in adult brain, whereas widespread neuronal apoptosis is unique for the early postnatal synaptogenesis period. The inflammatory response, in conjunction with excitotoxic and oxidative responses, is the major contributor to ischemic injury in both the immature and adult brain, but there are several areas where these responses diverge. We discuss the contribution of various inflammatory mechanisms to injury and repair after cerebral ischemia in the context of CNS immaturity. In particular, we discuss the role of lower expression of selectins, a more limited leukocyte transmigration, undeveloped complement pathways, a more rapid microglial activation, differences in cytokine and chemokine interplay, and a different threshold to oxidative stress in the immature brain. We also discuss differences in activation of intracellular pathways, especially nuclear factor $\kappa B$
\end{abstract}

and mitogen-activated protein kinases. Finally, we discuss emerging data on both the supportive and adverse roles of inflammation in plasticity and repair after stroke.

Copyright $\odot 2009$ S. Karger AG, Basel

\section{Introduction}

The pathophysiological role of acute inflammation in adult experimental stroke models has been demonstrated over the years and the relationships between the presence of reperfusion, gender, genetic background and the extent, timing and consequences of injury have been largely established [1]. The results of clinical trials using antiinflammatory drugs have been disappointing, however, indicating the complexity of the problem. Two concepts that dominated the neuroinflammation field for a long time - i.e. that the CNS is 'immunologically privileged' due to a relatively impenetrable blood-brain barrier (BBB) and that inflammation necessarily exacerbates neurodegeneration - have recently been challenged by the demonstration of a substantial cross-talk between peripheral and local immune components $[2,3]$ and a contribution of numerous inflammation-associated pathways in protection against chronic neurodegenerative diseases and repair [4-6].

\section{KARGER}

(C) 2009 S. Karger AG, Basel

Fax +41613061234 E-Mail karger@karger.ch www.karger.com www.karger.com/dne
Zinaida S. Vexler, $\mathrm{PhD}$

Department of Neurology, University of California, San Francisco

521 Parnassus Avenue, C215

San Francisco, CA 94143-0663 (USA)

Tel. +1 415502 2282, Fax +1 415502 5821, E-Mail Zena.Vexler@ucsf.edu 
One frequently overlooked aspect in the discussion of the role of inflammation in stroke is the impact of age, not only in the aging brain, but perhaps even more so in the immature brain. Inflammation is thought to play a substantial role in hypoxic-ischemic encephalopathy (HIE) and focal arterial stroke in human infants (reviewed in Ferriero [7]). Inflammation contributes differently to the pattern of injury in the infant brain, with regard to affected regions and vulnerable cell types, depending on whether the ischemic event occurs in a term or preterm baby and whether infection is present during HIE or precedes HIE (reviewed in Ferriero [7], Volpe [8] and McQuillen and Ferriero [9]).

Recent advances in the field of perinatal stroke $[7,10]$ have revealed that, strikingly, the incidence of arterial stroke in newborns, about $1 / 4,000$ term babies [11], is similar to that in the elderly. Although many intracellular mechanisms of neurodegeneration are shared across age groups, immaturity critically affects the brain's susceptibility to excitotoxic, oxidative and ischemic injury, especially during particular postnatal developmental stages (reviewed in Khwaja and Volpe [12], Wolfberg et al. [13] and Vexler and Ferriero [14]). While a rodent model of hypoxia-ischemia (HI), a model relevant to HIE in the term baby, has been available for decades [15], the ability to study age-appropriate models of ischemic stroke at term was not possible until about a decade ago when models of transient $[16,17]$ and permanent $[18]$ middle cerebral artery occlusion (MCAO) in postnatal day 7 (P7) rats were established. Therefore, a substantially more limited set of data are available for neonatal compared to adult focal stroke. Age differences in the mechanisms of stroke, some of them very striking, stem from immaturity of the CNS, including differences in the cross-talk between excitotoxic, oxidative and inflammatory injury mechanisms, creating 'windows of susceptibility' to ischemic and excitotoxic injury during embryonic and early postnatal brain development [7]. The mechanisms of ischemia-related damage in preterm babies (white matter lesions) have recently been reviewed $[12,13]$ and will not be discussed.

We will review data on specific aspects of neuroinflammation after stroke in relation to both acute injury and repair and will emphasize known similarities and differences in adult and neonatal rodents. Throughout the review we will first describe data on focal cerebral ischemia in the adult and then in the neonate after either focal stroke (if such data are available) or after HI. When discussing data obtained in two types of neonatal models, HI or MCAO, models used to mimic hypoxic encephalopathy and arterial stroke in term babies, respectively, we will not emphasize the commonalities and differences in the mechanisms of injury between the two models, which exist due to the presence of systemic hypoxia in the $\mathrm{HI}$ model and different location of the disrupted cerebral blood flow, but focus on the effects of immaturity on inflammation and injury after brain ischemia.

\section{Inflammation and Acute Injury after Experimental Stroke}

\section{Blood-Brain Barrier}

The integrity of the BBB is controlled by a number of different and partially independent components, including the presence of extracellular matrix, tight junctions, pericytes and astrocyte end feet $[19,20]$. Leukocyte entry into the CNS is restricted due to the $\mathrm{BBB}$ and the few leukocytes that are present in the CNS enter mostly through the cerebrospinal fluid and subarachnoid space [2].

In experimental adult stroke, the $\mathrm{BBB}$ is disrupted with the spatial-temporal extent of breakdown dependent on many factors, including increased levels of adhesion molecules and degradation of components of the basal lamina by metalloproteinases (MMPs) [21, 22], locally and systemically produced cytokines $[23,24]$, and activation of cells in the brain $[1,25]$. The effects of individual factors on $\mathrm{BBB}$ disruption after injury will be discussed later in this review.

Despite the common belief that the BBB in the neonate is substantially more permeable than in the adult, tight junctions are present early in embryonic development [26], restricting entrance of proteins into the brain in a controllable fashion. By birth the BBB is functional with no fenestrations [19]. Maturation of the BBB can substantially affect leukocyte passage from blood to parenchyma $[19,27]$.

A rather complex and unexpected effect of inflammatory stimuli on BBB integrity and leukocyte transmigration in rats has been reported during the first 3 weeks of life. Comparison of brain region sizes with accumulated IgG following intrastriatal injections of IL- $1 \beta$ or TNF- $\alpha$ in rats of different ages shows profoundly higher IgG accumulation in 21-day-old than in 2-hour-old rat pups [2831]. These data demonstrate that at birth $\mathrm{BBB}$ is functional and is in fact more resistant to inflammatory stress than juvenile brain. Age differences in the dynamics of BBB permeability as measured by IgG accumulation have been reported within $24 \mathrm{~h}$ after $\mathrm{HI}$ between $\mathrm{P} 7$ and $\mathrm{P} 30$ rats. Earlier IgG accumulation after $\mathrm{HI}$ has been found in P7 rats compared to $\mathrm{P} 30$ rats, indicating that $\mathrm{BBB}$ breakdown 
is more rapid in the younger rodents [32]. Comparisons of IgG accumulation between wild-type and neonatal MMP9 knockout mice $24 \mathrm{~h}$ after HI have shown reduced IgG accumulation in animals that lack MMP-9 [33], suggesting that BBB opening occurs shortly after HI and that MMP-9 contributes to this change. Our comparative study in $\mathrm{P} 7$ and adult rats subjected to transient MCAO shows that Evans blue extravasation, a measure of paracellular diffusion, the main path for bulk proteins and leukocytes to enter the brain, is low within $24 \mathrm{~h}$ after reperfusion in neonatal but is profoundly increased in adult rats [34]. A largely preserved paracellular diffusion in the latter study is associated with increased expression of several tight junction proteins [34], rather than with decreased expression seen in adult rats after similar injury. As we describe later, the lower extent of leukocyte extravasation after ischemic injury in neonatal rats $[35,36]$ may contribute to age differences in structural and functional disturbances of the $\mathrm{BBB}$ after ischemia.

\section{Leukocytes and Adhesion Molecules}

In humans, genomic profiling shows that neutrophils are the predominant source of released cytokines, chemokines and other molecules that activate the peripheral white blood cells after stroke [37]. Neutrophils are the earliest leukocyte subpopulation in the brain after stroke in adults (reviewed in Wang et al. [38]). They can contribute to the opening of the BBB in adult stroke, as has been shown by reduced injury and BBB disruption in chimeric mice, which lack MMP-9 in circulating immune cells but not in MMP-9-containing circulating immune cells [22]. They can also enhance injury via increased reactive oxygen species (ROS) production [39], acting both from the periphery and upon extravasation into injured tissue.

Leukocyte migration depends on the stepwise interaction between these cells and the vascular endothelium, including three main groups of cell adhesion molecules: selectins, the immunoglobulin superfamily and integrins [40]. The patterns of recruitment of monocytes and neutrophils are cytokine-specific: IL-1 $\beta$ triggers recruitment of neutrophils whereas TNF- $\alpha$ induces predominantly monocyte infiltration [41].

Inhibition of the early steps of leukocyte adhesion with antibodies or inhibitors of P- and E-selectin improves histological and neurological outcomes in rats and in mice deficient in P-selectin [42], whereas mice overexpressing P-selectin have exacerbation of infarcts [42]. Inhibition of neutrophil adhesion and migration do not reduce infarct volume in permanent ischemia [43].
Members of the immunoglobulin superfamily (such as ICAM-1), $\alpha$ - and $\beta$-integrins, and adhesion molecule families are involved in various aspects of communication between leukocytes and endothelium and extracellular matrix. Blockade or genetic depletion of ICAM-1 or the integrins CD11b, CD18, or both, improve outcome from experimental stroke in adults, in association with decreased neutrophil infiltration (reviewed in Wang et al. [38]), but no data are available for neonates.

In contrast to stroke in the adult, neutrophils do not transmigrate into the injured P7 brain following HI within $42 \mathrm{~h}$ [35] or they are present in the parenchyma only briefly [44]. Rather, neutrophils accumulate within vessels. This lack of transmigration in the neonate is unlikely to be due to an intrinsic inability of neutrophils to transmigrate into the brain, as they do transmigrate following permanent MCAO [45]. Although the effect of immaturity on leukocyte-endothelium interaction after injury is not well understood, P-selectin expression on endothelial cells is lower in the developing compared to adult brain. Also, there may be a less efficient adhesion of neutrophils to P-selectin [46, 47], which accounts for the more restricted neutrophil infiltration in immature compared to adult brain after ischemia. Circulating or marginated neutrophils, however, can contribute to $\mathrm{HI}$ injury in the newborn period since pups with neutrophils depleted prior to HI have reduced injury [36].

\section{Extracellular Matrix}

The MMPs, a family of zymogen proteases critically involved in the remodelling of the extracellular matrix, have been implicated in the pathophysiology of acute brain damage. MMP-9 plays a dual role in adult stroke - a damaging role acutely after stroke $[21,48]$ and a beneficial role in repair [49]. Increased expression of the pro- and active MMP-9 after adult focal stroke in rats temporally and spatially correlates with a loss of BBB integrity [21, 48]. Upregulation of brain MMP-9 levels by thrombolytic therapy with tissue plasminogen activator poses risks of cerebral hemorrhage after ischemic stroke [50]. A balance between MMPs and their inhibitors is important for the evolution of ischemic injury [51]. MMP-9 inhibition [52] or deletion [22, 48] reduces postischemic BBB disruption. MMP-2 seems to have a lesser effect on acute brain injury after focal ischemia but may play a role in recovery.

MMP-9 induction occurs in several phases following $\mathrm{HI}$ in neonatal rodents [53]. Excessive MMP-9 activation 
early after HI is deleterious to the immature brain, as demonstrated by a smaller injury size in MMP-9 knockout mice [33] and following inhibition of this protease with AG3340 [54]. Both reduced proteolysis of the extracellular matrix and cytokine release are the likely underlying mechanisms of protection. Hyperoxia is also injurious to the neonatal brain partly by inducing inflammation and MMP-2/9 activation [215]. Erythropoietin administration, which reduces accumulation of inflammatory mediators and MMP [215], provides both shortand long-term protection to the immature brain [216]. The adverse effect of prolonged MMP-9 inhibition on migration of neuroblasts from the subventricular zone (SVZ) has been shown in a model of adult stroke [49], but it is currently unknown whether late phases of MMP-9 induction [53] affect repair after neonatal HI or focal stroke. Other MMPs are also involved in ischemic brain damage. For example, MMP-12 mRNA and protein expression are significantly increased in the neonatal $\mathrm{HI}$ injured brain, and the levels of MMP-12 postively correlate with extent of tissue loss [217].

\section{Complement System}

The complement system is a potent mediator of inflammation. It is activated by three different pathways Clq-dependent (classical), mannose-binding-proteindependent and an alternative pathway - and plays an active role in ischemic injury in adult brain (reviewed in Komotar et al. [55]). Complement depletion induced by sLex-glycosylated complement inhibitory protein [56] or by cobra venum factor (CVF) [57] significantly reduces infarct volume in adult rat. A series of experiments in mice deficient in selected complement proteins - C1q, C3, C5 - subjected to transient focal cerebral ischemia have demonstrated that only C3-/- mice are protected, including both reduced infarct volume and neurological deficits [58]. Lack of C3 or inhibition of C3a receptor are associated with decreased granulocyte infiltration and reduced oxidative stress [58], demonstrating that C3 activation is the key constituent in complement-related inflammatory tissue injury following focal stroke. In immature rodents, complement activation, $\mathrm{C} 3$ and $\mathrm{Clq}$ deposition in particular, is seen within hours after HI [59, 60]. Pretreatment of neonatal rodents with CVF produces protection in some [57,60] but not all studies [61]. CVF-treated animals show minimal neuronal C3 deposition but unchanged C9 deposition [60]. In contrast to the adult, deletion of the Clq gene confers a significant and long-lasting protection in neonatal mice [62], suggesting that lack of $\mathrm{Clq}$ results in more complete inhibition of the cascade. Undeveloped nonclassical pathways of complement activation, both the mannose-binding protein and alternative pathways, which have been demonstrated in both human and rodent neonates [63, 64], are perhaps the key to the observed age-dependent effects. The mechanisms of protection in immature brain are not completely understood but include decreased C3 deposition and reduction in neutrophil activation [62].

\section{Microglia and Macrophages}

Microglia - resident macrophages - are the main cell type providing immunosurveillance in the brain [65] by stimulus-dependent activation in response to injury [66].

A large body of data utilizing cerebral ischemia of different severity in adults, with or without administration of anti-inflammatory agents, has suggested that a more severe ischemic brain injury is associated with higher macrophage densities and that attenuation of macrophage accumulation is protective (reviewed in Iadecola and Alexander [1], Wang et al. [38], and Jordan et al. [67]). Production of toxic products, inflammatory cytokines and chemokines in particular, is thought to be the predominant underlying mechanism. Activated microglial cells and macrophages can damage various cell types, including endothelial cells [25], oligodendrocytes [68], astrocytes [25] and neurons [69], thereby contributing to injury. However, it is still controversial whether microglial activation is beneficial or detrimental after stroke [70, 71]. A largely unanswered yet critical question is the relative contribution of parenchymal microglial cells, infiltrating macrophages derived from blood monocytes, and perivascular monocytes. A study of peripheral macrophage depletion did not affect infarct size [72] and might suggest that brain macrophages, rather than circulating cells, are important in ischemic pathogenesis. However, neuroprotection by injection of exogenous microglial cells into ischemic brain [71] or selective depletion of proliferating microglial cells [70] points to a beneficial role of these cells. Production of IGF-1 [70] and TNF- $\alpha$ [73] by activated microglia is suggested to contribute to this neuroprotection. The ability of microglial cells to modulate neurogenesis - hamper [74] or support neuronal differentiation [75] and survival [76] - also reveals the complexity of the modulatory role of these cells. Heterogeneity within the microglial pool [77], the stimulus type and 
the timing of activation [78] are likely to account for an array of microglial effects to injury.

Microglia populate the developing brain by birth [79] and gradually ramify during the first 2 weeks of life, in parallel with a decline of ongoing programmed cell death during this developmental stage. Macrophages are seen in abundance following neonatal HI [44, 80-82], producing inflammatory cytokines [82] and high levels of nitric oxide (NO) [83]; they remain in the injured brain for weeks $[45,84]$. Compared to the adults, macrophage accumulation in neonates is more rapid following transient MCAO. A 3- to 8-fold increase in the number of CD68positive macrophages in the injured cortex and basal ganglia occurs by $24 \mathrm{~h}$ after reperfusion [85]. Based on CD 45 expression, which is relatively low on resting microglia and microglia which undergo gradual activation, but is high on central monocyte lineage cells, in ischemic-reperfused neonatal brain, macrophages derive from resident microglia rather than invading monocytes within $24 \mathrm{~h}$ after reperfusion [86]. Different than in adults, the developmental status of microglial differentiation [87] and activation [88] in the early postnatal period may contribute to the rapid accumulation of activated microglia/macrophages in the injured neonatal brain. Microglial proliferation - another feature of microglial activation - is robust in neonates after transient MCAO; approximately a third of CD68-positive cells are newborn cells acutely after injury [85]. Microglia also contribute to $\mathrm{HI}$ injury in immature brain via complement activation and $\mathrm{C} 3$ deposition [60].

Pharmacological inhibition of cytokine accumulation, such as exogenous administration of the IL-1 receptor antagonist (IL-1ra) [89], or deficiency of inflammatory cytokines, such as IL-18 or IL-6, reduces injury and diminishes various signs of inflammation, including microglial activation $[89,90]$. Minocycline, a tetracycline family antibiotic with anti-inflammatory properties, protects adult brain against ischemia, in part by inhibiting microglial activation and proliferation [25,91, 92], but shows mixed results in neonatal rodents after focal stroke or HI $[84,93,94]$. In the neonatal studies, the notion that microglia contribute to, rather than limit acute ischemic injury in the immature brain comes from findings that reduction in injury is associated with diminished microglial activation/monocyte infiltration $[93,95]$ whereas injury remains unaffected when macrophage accumulation is unchanged [84]. At the same time, as we discuss later, several studies have shown that anti-inflammatory drugs thought to protect adult brain by reducing macrophage accumulation after stroke, protect neonatal brain without directly affecting inflammatory mechanisms associated with microglial activation [84, 85, 92, 96, 97]. Distinct steps of microglial maturation and differentiation (such as expression of major histocompatibility complex class II, cathepsin and other molecules [87]) and the propensity of neurons to undergo apoptosis in the developing brain may account for this age dependence of the microglial response.

\section{Other Inflammatory Cells}

Mast cells play a role in ischemic injury in adults and neonates. In adult mice subjected to transient MCAO and treated with either the mast cell inhibitor cromolyn or a mast cell degranulating agent, early brain swelling and ischemic BBB leakage are reduced by mast cell inhibition but enhanced by degranulation of these cells [98]. Consistent with these findings, mast cell-deficient adult rats have less brain swelling, neutrophil infiltration and a more preserved BBB in comparison to wild-type animals [98]. Stabilization of mast cells also reduces hemorrhage formation after administration of thrombolytics in experimental ischemic stroke [99].

Mast cells play an injurious role in neonatal HI [100] and focal stroke [101]. The number of mast cells is rapidly and dramatically increased in the ischemic hemisphere $[100,101]$. Stabilization of these cells by cromolyn significantly reduces brain damage [100]. The injurious effects of mast cells is thought to depend on TGF- $\beta$ and IL-9 [102].

$\mathrm{T}$ and $\mathrm{B}$ cells are seen days after injury in adult rodents after focal ischemia [103], whereas in neonates infiltration of these cells following neonatal HI and focal stroke may be less profound [44] or transient [45].

The relative contribution of pro-inflammatory mechanisms in astrocytes, as opposed to other roles of these cells in ischemic injury, is not well understood but astrocytes express the major histocompatibility complex [104] and can upregulate inducible nitric oxide synthase (iNOS) [105] and cytokine production [106].

\section{Mediators of Inflammation}

Clinical data on the pathophysiological role of inflammatory cytokines in adult human stroke (reviewed in Tang et al. [107] and Emsley and Hopkins [108]) and HIE in term babies [109-111] continue to emerge. We will only discuss experimental data on the role of cytokines and chemokines in injury exacerbation, protection and repair. 


\section{Cytokines}

Much of the data to date suggests that IL-1 potentiates brain injury in experimental stroke [112]. In adults, IL-1 $\beta$ administration increases brain damage [113] whereas mice deficient in both IL-1 isoforms, IL-1 $\alpha$ and IL-1 $\beta$, have smaller infarcts compared to wild-type mice [114]. Administration of IL-1ra [23, 115], or its overexpression by adenoviral vectors [116] has been shown to reduce neurologic deficits and infarct size in adult rodents following focal stroke. The extent of IL-1 receptor 1 (IL-1R1)-dependent and IL-1R1-independent effects is not fully understood. Protection was not observed in IL-1R1-deficient mice following MCAO [112] whereas observed after HI in the adult [117]. Reasons for these opposing observations are unclear, which, however, indicate the complexities of this line of research. Regardless, IL-1 $\beta$ activation requires cleavage by caspase- 1 , and blockade of caspase-1 activation and its association with other proteins needed for IL-1 $\beta$ and IL-18 activation is protective in a thromboembolic stroke model [118].

Following neonatal HI, mRNA [102] and protein IL$1 \beta$ [89] expression are rapidly increased and their levels can be further amplified by concomitant infection or manipulations within the oxidant pathways [119]. A major, rapid and sustained increase in IL-1 $\beta$ protein occurs in the circulation shortly after transient MCAO in neonatal rats [86]. The increase is followed by elevated levels of IL$1 \beta$ in the ischemic-reperfused brain [86]. IL-1 $\beta$ can trigger a local inflammatory reaction and drive neutrophils into the brain, but neutrophil accumulation and BBB disruption induced by IL-1 $\beta$ greatly depend on age, as was shown by comparing the effects in P0 and P21 rats following intrastriatal IL-1 $\beta$ injection [28]. The scope of the IL-1 $\beta$-mediated effects on neonatal brain injury is not fully understood. Genetic deletion of IL-1 $\beta$ or IL-1 $\alpha$ alone, or in combination (IL-1 $\alpha \beta$ knockout), does not protect 1 week after HI injury [120], whereas administration of IL-1ra, which reverts HI-induced upregulation of IL-1 $\beta$, protects neonatal brain [121]. These discrepancies may be due to multiple or desynchronized effects of IL-1 which are all abrogated in knockout mice but not following pharmacologic treatment.

IL-1 $\beta$ plays a major role in worsening $\mathrm{HI}$ injury after infection. Compared to $\mathrm{HI}$ alone, increased injury, elevated IL-1 $\beta$ and significantly downregulated IL-1ra expression were observed following HI combined with infection (modeled by lipopolysaccharide exposure) [121]. These results suggest that similar to the adult, the pro- inflammatory shift of IL-1 $\beta$ to IL-1ra might play a role in the initiation of perinatal brain damage [121].

TNF- $\alpha$ exhibits pleiotropic functions in the mature ischemic brain [122]. It is rapidly upregulated in the adult brain after ischemia [123], with expression initially observed in neurons, then in microglia and some astrocytes. While inhibition of TNF- $\alpha$ reduces ischemic brain injury [124] and administration of recombinant TNF- $\alpha$ protein after stroke onset worsens ischemic brain damage [125], mice deficient in TNF receptors (TNFR) have larger infarcts [126]. One reason for this disparity might be due to different pathways through which TNF- $\alpha$ signals, and the timing of TNF- $\alpha$ manipulation. Most effects induced by TNF- $\alpha$ are mediated by TNFR 1 , which contains a death domain and may act as a bifurcation point for signaling related to cell death or cell survival. By reacting with Fas-associated death domain (FADD) and caspase-8, TNF- $\alpha$ may lead to apoptosis. Signaling through TNF receptor 2 may lead to anti-inflammatory and anti-apoptotic functions [127]. Furthermore, pre-insult TNF- $\alpha$ is associated with a preconditioning response, whereas post-insult TNF- $\alpha$ administration is detrimental (reviewed in Hallenbeck [128]). Alternatively, the origin of TNF- $\alpha$ production may be a key to the observed effects. A recent stroke study utilizing TNF- $\alpha$ knockout and bone marrow-chimeric mice with manipulated cells of the monocyte lineage demonstrates that TNF- $\alpha$ is protective when it is produced in microglial cells but is injurious when produced by leukocytes [73].

The pathophysiological role of TNF- $\alpha$ in neonatal stroke is assumed but has yet to be proven. Neonatal mice lacking functional Fas death receptors are resistant to HI brain injury [129], presumably in part due to its dependence on TNF- $\alpha$. The extent of TNF- $\alpha$-mediated effects on acute injury may not be profound in the neonate, however, as the levels of TNF- $\alpha$ in injured brain remain largely unchanged within 1-24 h following focal stroke [84].

IL-6 is largely thought of as a pro-inflammatory cytokine, but whether it plays a significant role in ischemic stroke is far from clear. IL-6-deficient adult mice have similar-sized infarcts compared to wild-type mice, suggesting that it does not participate in ischemic pathogenesis [130]. However, other studies suggest either a beneficial [131] or detrimental role [132]. IL-6-stimulated primary microglial cells increase the production of IL-1 $\beta$, TNF- $\alpha$, and Cox- 2 and significantly decrease survival of neurons [133]. In the neonatal brain, IL- 6 appears transiently several hours after the insult [134]. Blocking its actions protects the neonatal injured brain [89]. IL- 6 has been shown to adversely affect neurogenesis after adult 
stroke [74], but its effect on neurogenesis in the immature brain is not known.

IL-18 is a pro-inflammatory cytokine from the IL-1 family that becomes bioactive upon cleavage by caspase-1 in a way similar to that for IL-1 $\beta$. Genetic deletion of the IL-18 gene does not affect injury early after focal stroke in the adult [135], whereas genetic deletion of caspase-1 is protective, as is pharmacological disruption of IL-18 and IL-1 $\beta$ processing by inhibiting their assembly with caspase-1 [118]. The discrepancy between data obtained using IL-18 genetic and pharmacologic manipulations in adult stroke models is not well understood but may be due to elimination of both supportive and injurious effects of IL-18 in knockouts.

In contrast to that in adults, genetic deletion of IL-18 reduces HI injury in neonates [90]. Interestingly, IL-18 deletion more robustly protects the neonatal brain from $\mathrm{HI}$ than genetic deletion of IL-1 $\beta$. Endogenous levels of IL-18 in the neonate appear to be higher than in the adult, and have thus been suggested to play a role in its age-dependent effects following HI injury [120]. Increased IL-18 expression is reported in microglia after neonatal HI [90], but protection achieved by minocycline is not associated with reduced brain IL-18 levels in neonatal focal stroke [84]. Comparative data between neonatal and juvenile animals subjected to $\mathrm{HI}$ show that a higher rate of neurogenesis in juvenile rats is associated with higher IL18 brain levels; a supportive role of IL-18 in neurogenesis has been suggested [136].

Expression of IL-9, a pro-inflammatory Th2 cytokine, is developmentally regulated and is the highest in the newborn brain [137]. The IL-9/IL-9 receptor pathway has been shown to have a direct anti-apoptotic action in the newborn neocortex [137]. Little is known about its role in adult experimental stroke, but this cytokine has been shown to contribute to $\mathrm{HI}$ and excitotoxic injury in the developing brain $[102,138,139]$. In particular, IL-9-mediated activation of mast cells and injury exacerbation has been shown in an excitotoxicity model in newborn mice $[138,139]$.

IL-10 is a pleiotropic Th2 cytokine that is synthesized in the CNS and can act on both hematopoietic and nonhematopoietic cells. It can reverse injury caused by IL-1 $\beta$, TNF- $\alpha$ and IL-6 [140]. Exogenous administration [141] and gene transfer of IL-10 [142] both appear to have a protective effect in adult global cerebral ischemia models. In a white matter lesion model in P5 rats, protection is seen when IL-10 is administered after the insult, whereas treatment prior to or at the time of the insult is ineffective [140]. Reduction of macrophage accumulation in the injured brain is considered to be one of the mechanisms of IL-10.
Scarce data on the role of IL-4 in stroke suggests that this cytokine affects injury by modulating microglial activation, presumably by attenuation of cytokine production $[75,143]$, rather than by affecting neurons directly. Pretreatment of microglial cells with IL- 4 has been shown to enhance adult neurogenesis [75]. Treatment of P5 rodents prior to induction of excitotoxic injury does not exacerbate injury, perhaps suggesting that IL- 4 contributes to endogenous protection in a newborn brain [138].

\section{Chemokines}

Chemoattractant cytokines, or chemokines, exert a variety of physiological functions, including control of cell migration, proliferation, differentiation and angiogenesis [144]. They act through G-protein-coupled receptors [144] and are classified as C, CC, CXC, and CX3C based on the positions of key cysteine residues.

The central role of monocyte chemoattractant protein1 (MCP-1) and its receptor, CCR2, in monocyte transmigration into the adult brain is demonstrated by profound deficits in the recruitment of monocytes to sites of inflammation and injury in CCR2-deleted mice [145], and increased brain cytokine production and brain injury in CCR2-overexpressing mice [146]. MCP-1 inhibition or deficiency is associated with reduced injury [147, 148], whereas overexpression of MCP-1 exacerbates injury [149].

In neonatal rodents, MCP-1 expression is increased following HI [150] and transient focal ischemia [84]. The pathophysiologic role of MCP-1 in neonatal brain injury is evident from protection by functional inactivation of MCP-1 after insult [151] or in mice with depleted IL-1converting enzyme [150]. Despite increased MCP-1 expression in several brain cell types, accumulation of monocyte-derived macrophages is low following focal ischemia-reperfusion [86] and protection achieved by minocycline administration is not associated with decreased brain MCP-1 concentration [84].

Macrophage inflammatory protein- $1 \alpha$ is induced in animal models of focal cerebral ischemia in adults [152] and in neonates [82]. It is thought to contribute to ischemic injury by regulating monocyte and microglial recruitment and activation and disruption of the BBB [153].

IL- 8 and CINC-1/KC are ELR+ CXC chemokines that exhibit potent chemoattractant activities towards neutrophils and show angiogenic activities [154]. IL-8 [155] and CINC-1 [29] injected into the brain are thought responsible for the massive neutrophil-mediated BBB disruption. IL-1 $\beta$ mediates BBB permeability in part through 
CINC-1 increase in the brain. Elevated postischemia CINC-1 contributes to injury; administration of a neutralizing CINC-1 antibody protects the adult brain [156].

The magnitude of CINC-1-induced neutrophil-mediated brain inflammation and BBB breakdown depends on age [29] - a profoundly higher neutrophil extravasation and BBB disruption occurs in juvenile (P21) than in adult rats following CINC-1 injection into the brain [29]. Data are accumulating on the role of CINC-1 in neonatal stroke. Minimal neutrophil accumulation in the neonatal brain following focal transient ischemia [157] is associated with the rapidly and profoundly elevated peripheral CINC-1 levels [86] as well as with elevated levels of this chemokine in the brain. Attenuation of the peripheral levels of CINC1 enhances injury [34], suggesting a protective potential of this chemokine early after neonatal stroke. So far, there have been no reports on the effect of CINC-1 in angiogenesis and repair after neonatal brain injury.

SDF-1 (CXCL12) may play an important role in homing stem cells to regions of ischemic injury [158]. SDF-1 is expressed in the ischemic penumbra, in reactive astrocytes in particular. Inhibiting SDF-1 reduces stem cell migration into ischemic tissue [159]. SDF-1 expression is briefly upregulated by reactive astrocytes following neonatal $\mathrm{HI}$ injury, suggesting that the period of time for endogenous SDF-1-mediated chemotaxis and recruitment of reparative cells may be narrow [160].

\section{ROS as Mediators and Triggers of Inflammation}

Oxidative stress and inflammation are tightly linked. Once activated, the inflammatory cells generate ROS. $\mathrm{ROS}$, in turn, can trigger an inflammatory response. Superoxide anion plays an important role in ischemic injury. It is generated via xanthine dehydrogenase (COX), xanthine oxidase and NADPH oxidase and is utilized via superoxide dismutase in the cytosol (CuZnSOD) and mitochondria. CuZnSOD overexpression protects the adult brain from focal stroke [161] by increased superoxide utilization. In the immature brain, CuZnSOD overexpression, however, exacerbates brain injury after HI [162, 163]. Low expression and activity of the $\mathrm{H}_{2} \mathrm{O}_{2}$-utilizing enzymes glutathione peroxidase and catalase are the underlying causes of $\mathrm{H}_{2} \mathrm{O}_{2}$ accumulation in injury in the developing brain [164]. Enhanced activity of antioxidant metabolism via overexpression of glutathione peroxidase or deletion of $\mathrm{CuZnSOD}$ are protective [165], supporting the notion on the pro-injurious role of oxidative stress in neonatal ischemic brain injury.

Inflammation after Stroke in the

Developing Brain and Adult Brain
Activation of NADPH oxidase, a major superoxideproducing enzyme in immune cells and microglia, contributes to ischemic injury in adult rodents, as evident from protection by pharmacologic inhibition or genetic deletion of one of the subunits of this multicomponent enzyme, gp91-phox $[166,167]$. In contrast to the adult, genetic deletion of gp91-phox increases the extent of brain injury in two neonatal models, the HI model in P9 mice and the ibotenate-induced excitotoxic model in P5 mice [119]. More severe HI injury that parallels reduced NADPH oxidase activity is associated with increased levels of IL-1 $\beta$ and accumulation of galectin-3-positive microglia. The underlying mechanisms for this phenomenon are not understood. Considering that NADPH oxidase is necessary for the phagocytotic process, one plausible explanation would be a more limited phagocytosis of apoptotic neurons by microglial cells deficient in NADPH oxidase. Limited removal of apoptotic cells, in turn, leads to increased necrosis and more extensive injury. The cellular source of $\mathrm{NADPH}$ oxidase may also determine the role of this enzyme in ischemic damage [166].

NO generation can have opposing roles in the process of ischemic injury, protective when generated by endothelial NOS and detrimental when produced by neuronal NOS and iNOS [168]. iNOS is capable of producing large amounts of NO over extended periods [169], which, in turn, directly damages cell constituents, produces a number of toxic species, such as peroxynitrate [170], activates COX-2 [171], or inflammatory cells [169]. Deletion of iNOS [172] or iNOS inhibition $[83,173,174]$ is neuroprotective in adult stroke models and neonatal HI models. Following neonatal focal ischemia-reperfusion, iNOS inhibition attenuates caspase- 3 activation without affecting activation or proliferation of microglial cells [85].

\section{Intracellular Inflammatory Signaling Pathways}

Cerebral ischemia upregulates gene expression, including rapid transcriptional activation of pro-inflammatory factors in both age groups $[175,176]$. We will discuss some of the transcription factors that contribute substantially to the inflammatory response.

\section{Nuclear Factor кB}

Nuclear factor $\kappa \mathrm{B}(\mathrm{NF}-\kappa \mathrm{B})$ is a transcription factor involved in the regulation of inflammation and neuronal death after stroke $[177,178]$. NF- $\mathrm{BB}$ is normally located

Dev Neurosci 2009;31:378-393 
in the cytoplasm as a heterodimer composed of p65 and p50 subunits, bound to the endogenous inhibitor protein ІкB. Dissociation of this complex by phosphorylation of I $\kappa$ B by an upstream IкB kinase (IKK) liberates NF- $\kappa$ B, allowing it to translocate to the nucleus and bind to functional $\kappa \mathrm{B}$ sites. NF- $\kappa \mathrm{B}$ induces several major genes involved in inflammation, such as TNF- $\alpha$, ICAM-1, COX2, iNOS and IL-6. Pharmacological inhibition of early stages of the pathway activation [179], depletion of one of the subunits, p50 [180], or inhibition of NF- $\kappa$ B-dependent genes [181] typically reduces local inflammation and protects. NF- $\kappa \mathrm{B}$ can affect neurons directly, as shown by protection of cultured neurons both by selective inhibition of IKK and targeted deletion of Iкbкb, which encodes IKK2 [178]. In adult stroke, deletion of neuronal Iкbкb markedly reduces infarct size whereas constitutive activation of IKK2 enlarges the infarct [178]. However, the function of NF- $\kappa \mathrm{B}$ in stroke is still controversial [182], as inhibition of NF- $\kappa \mathrm{B}$ with diethyldithiocarbamate, for example, enhances neuronal DNA fragmentation and enlarges infarct [183].

Recent studies in neonatal rodents have demonstrated that NF- $\kappa$ B plays a dual role in HI $[184,185]$. NF- $\kappa$ B undergoes two waves of activation within $24 \mathrm{~h}$ after $\mathrm{HI}$, with opposite effects on injury [185]. NF- $\kappa B$ inhibition early after HI (0.5-6 h) prevents upregulation and accumulation of the p53 in the nucleus, reduces mitochondrial cytochrome $c$ release and activation of caspase- 3 and results in major neuroprotection 6 weeks after injury [184]. In contrast, inhibition of both early and late (at $24 \mathrm{~h}$ ) phases of activation abolishes the effect on neuronal apoptosis and even exacerbates injury $[185,186]$. Interestingly, late NF- $\kappa \mathrm{B}$ activation does not increase cytokine mRNA levels. While these data show that the kinetics of NF- $\kappa B$ is different in neonatal compared to adult rodents after ischemia-related events, the timing of NF- $\kappa \mathrm{B}$ activation seems to play a key role in the ultimate outcome of $\mathrm{HI}$; injury or protection. Cell origin of NF- $\kappa \mathrm{B}$ activation after $\mathrm{HI}$, which is currently not described, may appear critical. The severity of insult (duration of hypoxia) may also affect the relative contribution of the anti-inflammatory compared to anti-apoptotic mechanisms of NF- $\kappa \mathrm{B}$ inhibition [187].

\section{Mitogen-Activated Protein Kinases}

A family of mitogen-activated protein kinases (MAPKs) is comprised of three subfamilies, extracellular signal-regulated kinase, p38, and c-Jun $\mathrm{N}$-terminal ki- nase (JNK). The kinases are ubiquitously expressed and, depending on the context and cell type, exert a broad range of functions via activation of distinct transcription factors.

Extracellular signal-regulated kinase $1 / 2$ activation is generally neuroprotective in both adult and neonatal brain injury whereas MAPK p38 is best known for transduction of stress-related signals, regulation of inflammatory gene production [188] and NF- $\kappa \mathrm{B}$ recruitment to selected targets [189]. Following forebrain ischemia in rodents, phosphorylated $\mathrm{p} 38$ is detected in the hippocampus within neuron-like [190] and microglia-like [191] cells, suggesting a role in the endogenous inflammatory response. Furthermore, MAPK p38 inhibitors reduce brain injury and neurological deficits in adult focal cerebral ischemia (reviewed in Mehta et al. [192]). While p38 inhibitors show some promise in adult stroke models, the role of this kinase is less clear in neonatal ischemic injury. While increased p38 phosphorylation is observed in neonatal rat brain after HI [193], a profound reduction of p38 phosphorylation is seen in injured brain after neonatal transient focal ischemia [84]. Additional information is needed to reconcile whether cell type-specific activation of p38 accounts for the observed age differences.

JNK isoforms (JNK1/2/3) have distinct roles in cerebral ischemia. JNK1 is thought to play a major role in ensuring high levels of basal JNK activity in the brain. In contrast, targeted deletion of JNK3 not only reduces the stress-induced JNK activity, but also protects mice from brain injury by reducing apoptosis [194]. A protective effect of JNK3 deletion and reduction of caspase-3-dependent apoptosis has recently been shown on $\mathrm{HI}$ in neonatal mice [195], similar to that observed against cerebral ischemia in the adult. MAPKs activate the mixed lineage kinase family (MLK), which in turn regulate JNK. The MLK inhibitor CEP-1347 protects the immature brain from HI [218].

\section{Neuroprotection and Anti-Inflammatory Strategies}

Data from pharmacological and knockout studies have consistently shown that at least some neuroprotective effect can be achieved after adult experimental stroke via reduction of local inflammation, with variable magnitude and length of protection, which, in part, depends on the timing of intervention (reviewed in Iadecola and Alexander [1] and Wang et al. [38]). The use of the same anti-inflammatory agents that induce protection after adult stroke, minocycline for example, pro- 
duced mixed results in neonatal rodents after focal stroke or HI $[84,93,94]$. A broad range of anti-inflammatory drugs that target various intracellular pathways in microglial cells protect the immature brain against injury. While in many but not all cases, protection is associated with reduced macrophage densities or diminished accumulation of CD68-positive cells in injured regions, interestingly, in a growing number of cases protection occurs through anti-apoptotic mechanisms, without directly affecting activation of inflammatory pathways (such as cytokines, NO); a phenomenon shown for minocycline [84, 92, 97], 2-iminobiotin [96], chloroquine [95], and aminoguanidine [85]. Thus, the interplay between injury, neuronal cell death, and inflammation is not fully understood.

A number of recent studies suggest that gender plays an important role in the pathogenesis of inflammatory injury. In neonatal rodents, the gender of the animal strongly influences activation of apoptotic pathways [196, 197] and affects $\mathrm{HI}$ injury outcome. In fact, gender differences have been shown in neonatal rodents in response to treatment with iNOS inhibitor 2-iminobiotin, with protection in female but not male pups [198]. Protection is associated with inhibition of apoptotic pathways rather than alteration in NO signaling [198].

Therapeutic hypothermia, so far, is the most successful and consistent intervention that works in all age groups in humans, but the mechanisms of protection are yet to be fully understood. There are certainly abundant studies to support an anti-inflammatory effect of hypothermia, among other mechanisms (reviewed in Han and Yenari [199]). Some studies in neonatal rats have shown that combining hypothermia with a therapeutic, such as topiramate [200], can extend the 'therapeutic window'.

\section{Inflammation, Neurogenesis and Repair}

Ischemic stroke induced by transient $\mathrm{MCAO}$ gives rise to cell proliferation in the SVZ in both adult [201, 202] and neonatal $[203,204]$ brains. The neuroblasts migrate from the SVZ into the damaged tissue, and differentiate, but only a few survive [201,205]. The microenvironment in their vicinity may play a key role in survival $[76,206]$. The reciprocal relationship between inflammation and neurogenesis was initially shown in adult stroke by demonstrating the adverse effects of IL-6 [74] and TNF- $\alpha$ [207] produced by activated microglia. Microglial cells produce an array of mediators that can be harmful dur- ing acute disease but beneficial during repair (e.g. NO, MMPs, chemokines and complement). But these cells also produce supportive and anti-inflammatory factors, such as IGF-1, TGF- $\beta_{1}$, GDNF and IL-10. A possibility of switching the microglial phenotype from destructive to beneficial with modulation of the environment after brain injury has been demonstrated $[5,75,133,208]$, with effects on gliogenesis and oligodendrogenesis $[209,210]$. IGF-1 produced by microglia in the SVZ can promote proliferation and differentiation of neural stem cells [211]. Oxidative stress and inflammation are now shown to bias differentiation toward astrocytes, for example, by modulating activity of the anti-inflammatory gene Sirt1 [212].

So far, only a few studies have linked neurogenesis and inflammation in the newborn brain. One recent study [136] demonstrates that the effects of $\mathrm{HI}$ on proliferation and differentiation are different in the immature (P9) and juvenile (P21) mouse hippocampus. Increased microglial proliferation and higher MCP-1 and IL-18 levels, which precede neurogenesis in the juvenile hippocampus, are suggested to contribute to neurogenesis [136]. IGF-1 and MCP-1, likely produced in microglia, may contribute to sustained neurogenesis after HI [213].

\section{Conclusion}

Stroke triggers a robust inflammatory response in both the adult and neonatal brain. A large body of data have linked postischemic inflammation to exacerbation of brain damage. Many contributing inflammatory mechanisms and pathways after cerebral ischemia are similar in adults and neonates. Yet, the immaturity of the immune system, an ongoing developmental neuronal apoptosis, and a different balance between pro- and antioxidant enzymes create a 'window of susceptibility' to ischemic injury during early postnatal brain development. Some examples include the opposing effects of oxidant pathway manipulation (CuZnSOD, NADPH oxidase), differences in leukocyte-endothelial cell communication, and often distinct intracellular signaling within inflammatory pathways (NF- $\mathrm{B}, \mathrm{MAPK} \mathrm{p} 38$ ). The mechanisms of beneficial effects for some anti-inflammatory drugs after neonatal HI and focal stroke - reduction of caspase-3 activation rather than a decrease in cytokine accumulation - await explanation.

For a long time, the dominant concept was that inflammation necessarily leads to neurodegeneration. However, recent data show that inflammation, via microglia in particular, may support rather than harm neu- 
rogenesis and long-term recovery. The role of inflammation in ischemia-related brain injury - destructive or protective - may depend on the severity of ischemia, duration of activation, and stage of stroke progression. A recent study that demonstrated the opposing effects of prenatal inflammation - a profound exacerbation of HI severity in neonatal mice but protection in adult mice [214] - suggests that inflammation can reprogram brain sensitivity to ischemia, perhaps over a life span. Therefore, it is imperative to understand when, how and for how long it is safe to use anti-inflammatory agents in injured neonates, without inducing adverse effects over a longer term. Fu- ture work should address how the immune system moves from damaging to protective/restorative responses and how these stages are affected by factors like gender and genetic background.

\section{Acknowledgements}

This work was supported by grants from NIH NINDS RO1 NS44025 (Z.S.V.), American Heart Association Grant-in-Aid (Z.S.V.), NIH NINDS RO1 NS40516 (M.A.Y.), and American Heart Association Established Investigator Award (M.A.Y.).

\section{References}

1 Iadecola C, Alexander M: Cerebral ischemia and inflammation. Curr Opin Neurol 2001; 14:89-94.

-2 Ransohoff RM, Kivisakk P, Kidd G: Three or more routes for leukocyte migration into the central nervous system. Nat Rev Immunol 2003;3:569-581.

-3 Perry VH: The influence of systemic inflammation on inflammation in the brain: implications for chronic neurodegenerative disease. Brain Behav Immun 2004;18:407-413.

-4 Britschgi M, Wyss-Coray T: Immune cells may fend off Alzheimer disease. Nat Med 2007;13:408-409.

5 Ziv Y, Ron N, Butovsky O, Landa G, Sudai E, Greenberg N, Cohen H, Kipnis J, Schwartz M: Immune cells contribute to the maintenance of neurogenesis and spatial learning abilities in adulthood. Nat Neurosci 2006;9: 268-275.

-6 Ekdahl CT, Kokaia Z, Lindvall O: Brain inflammation and adult neurogenesis: the dual role of microglia. Neuroscience 2009;158: 1021-1029.

77 Ferriero DM: Neonatal brain injury. N Engl J Med 2004;351:1985-1995.

-8 Volpe JJ: Neurobiology of periventricular leukomalacia in the premature infant. Pediatr Res 2001;50:553-562.

-9 McQuillen PS, Ferriero DM: Selective vulnerability in the developing central nervous system. Pediatr Neurol 2004;30:227-235.

10 Nelson KB, Lynch JK: Stroke in newborn infants. Lancet Neurol 2004;3:150-158.

-11 deVeber G, Roach ES, Riela AR, Wiznitzer M: Stroke in children: recognition, treatment, and future directions. Semin Pediatr Neurol 2000;7:309-317.

12 Khwaja O, Volpe JJ: Pathogenesis of cerebral white matter injury of prematurity. Arch Dis Child Fetal Neonatal Ed 2008;93:F153-F161.

-13 Wolfberg AJ, Dammann O, Gressens P: Antiinflammatory and immunomodulatory strategies to protect the perinatal brain. Semin $\mathrm{Fe}$ tal Neonatal Med 2007;12:296-302.
14 Vexler ZS, Ferriero DM: Mechanisms of ischemic cell death in the developing brain in Chan P (ed): Handbook of Neurochemistry and Molecular Neurobiology. Berlin, Springer, 2007.

15 Rice JE 3rd, Vannucci RC, Brierley JB: The influence of immaturity on hypoxic-ischemic brain damage in the rat. Ann Neurol 1981;9:131-141.

16 Ashwal S, Cole DJ, Osborne S, Osborne TN Pearce WJ: A new model of neonatal stroke: reversible middle cerebral artery occlusion in the rat pup. Pediatr Neurol 1995;12:191196.

17 Derugin N, Ferriero DM, Vexler ZS: Neonatal reversible focal cerebral ischemia: a new model. Neurosci Res 1998;32:349-353.

18 Renolleau S, Aggoun-Zouaoui D, Ben-Ari Y, Charriaut-Marlangue C: A model of transient unilateral focal ischemia with reperfusion in the P7 neonatal rat: morphological changes indicative of apoptosis. Stroke 1998; 29:1454-1460; discussion 1461

19 Engelhardt B: Development of the bloodbrain barrier. Cell Tissue Res 2003;314:119129.

20 Zlokovic BV: The blood-brain barrier in health and chronic neurodegenerative disorders. Neuron 2008;57:178-201.

21 Romanic AM, White RF, Arleth AJ, Ohlstein $\mathrm{EH}$, Barone FC: Matrix metalloproteinase expression increases after cerebral focal ischemia in rats: inhibition of matrix metalloproteinase- 9 reduces infarct size. Stroke 1998;29:1020-1030.

22 Gidday JM, Gasche YG, Copin JC, Shah AR, Perez RS, Shapiro SD, Chan PH, Park TS: Leukocyte-derived matrix metalloproteinase- 9 mediates blood-brain barrier breakdown and is proinflammatory after transient focal cerebral ischemia. Am J Physiol Heart Circ Physiol 2005;289:H558-H568.

23 Allan SM, Tyrrell PJ, Rothwell NJ: Interleukin-1 and neuronal injury. Nat Rev Immunol 2005;5:629-640.
24 Pan W, Ding Y, Yu Y, Ohtaki H, Nakamachi T, Kastin AJ: Stroke upregulates TNFalpha transport across the blood-brain barrier. Exp Neurol 2006;198:222-233

25 Yenari MA, Xu L, Tang XN, Qiao Y, Giffard RG: Microglia potentiate damage to bloodbrain barrier constituents: improvement by minocycline in vivo and in vitro. Stroke 2006;37:1087-1093.

26 Kniesel U, Risau W, Wolburg H: Development of blood-brain barrier tight junctions in the rat cortex. Brain Res Dev Brain Res 1996;96:229-240.

-27 Saunders NR, Knott GW, Dziegielewska KM: Barriers in the immature brain. Cell Mol Neurobiol 2000;20:29-40.

$\checkmark 28$ Anthony DC, Bolton SJ, Fearn S, Perry VH: Age-related effects of interleukin-1 beta on polymorphonuclear neutrophil-dependent increases in blood-brain barrier permeability in rats. Brain 1997;120:435-444.

29 Anthony D, Dempster R, Fearn S, Clements J, Wells G, Perry VH, Walker K: CXC chemokines generate age-related increases in neutrophil-mediated brain inflammation and blood-brain barrier breakdown. Curr Biol 1998;8:923-926.

30 Schnell L, Fearn S, Schwab ME, Perry VH, Anthony DC: Cytokine-induced acute inflammation in the brain and spinal cord. J Neuropathol Exp Neurol 1999;58:245-254.

- 31 Blamire AM, Anthony DC, Rajagopalan B, Sibson NR, Perry VH, Styles P: Interleukin1beta-induced changes in blood-brain barrier permeability, apparent diffusion coefficient, and cerebral blood volume in the rat brain: a magnetic resonance study. J Neurosci 2000;20:8153-8159.

32 Qiao M, Malisza KL, Del Bigio MR, Tuor UI: Correlation of cerebral hypoxic-ischemic $\mathrm{T} 2$ changes with tissue alterations in water content and protein extravasation. Stroke 2001; 32:958-963. 
-33 Svedin P, Hagberg H, Savman K, Zhu C, Mallard C: Matrix metalloproteinase-9 gene knock-out protects the immature brain after cerebral hypoxia-ischemia. J Neurosci 2007; 27:1511-1518.

34 Faustino J, Liu B, Lee S, Derugin N, Wendland MF, Vexler ZS: Blockade of endogenous cytokine-induced neutrophil chemoattractant protein 1 exacerbates injury after neonatal stroke. International Stroke Conference, San Diego, 2009.

-35 Hudome S, Palmer C, Roberts RL, Mauger D, Housman C, Towfighi J: The role of neutrophils in the production of hypoxic-ischemic brain injury in the neonatal rat. Pediatr Res 1997;41:607-616.

>36 Palmer C, Roberts RL, Young PI: Timing of neutrophil depletion influences long-term neuroprotection in neonatal rat hypoxicischemic brain injury. Pediatr Res 2004;55: 549-556.

-37 Du X, Tang Y, Xu H, Lit L, Walker W, Ashwood P, Gregg JP, Sharp FR: Genomic profiles for human peripheral blood T cells, B cells, natural killer cells, monocytes, and polymorphonuclear cells: comparisons to ischemic stroke, migraine, and Tourette syndrome. Genomics 2006;87:693-703.

38 Wang Q, Tang XN, Yenari MA: The inflammatory response in stroke. J Neuroimmunol 2007; 184:53-68.

-39 Chou WH, Choi DS, Zhang H, Mu D, McMahon T, Kharazia VN, Lowell CA, Ferriero DM, Messing RO: Neutrophil protein kinase Cdelta as a mediator of stroke-reperfusion injury. J Clin Invest 2004;114:49-56.

40 del Zoppo G, Ginis I, Hallenbeck JM, Iadecola C, Wang X, Feuerstein GZ: Inflammation and stroke: putative role for cytokines, adhesion molecules and iNOS in brain response to ischemia. Brain Pathol 2000;10: 95-112.

-41 Blond D, Campbell SJ, Butchart AG, Perry $\mathrm{VH}$, Anthony DC: Differential induction of interleukin-1beta and tumour necrosis factor-alpha may account for specific patterns of leukocyte recruitment in the brain. Brain Res 2002;958:89-99.

$\checkmark 42$ Connolly ES Jr, Winfree CJ, Prestigiacomo CJ, Kim SC, Choudhri TF, Hoh BL, Naka Y, Solomon RA, Pinsky DJ: Exacerbation of cerebral injury in mice that express the P-selectin gene: identification of P-selectin blockade as a new target for the treatment of stroke. Circ Res 1997;81:304-310.

-43 Prestigiacomo CJ, Kim SC, Connolly ES Jr, Liao H, Yan SF, Pinsky DJ: CD18-mediated neutrophil recruitment contributes to the pathogenesis of reperfused but not nonreperfused stroke. Stroke 1999;30:1110-1117.

-44 Bona E, Andersson AL, Blomgren K, Gilland E, Puka-Sundvall M, Gustafson K, Hagberg $\mathrm{H}$ : Chemokine and inflammatory cell response to hypoxia-ischemia in immature rats. Pediatr Res 1999;45:500-509.
45 Benjelloun N, Renolleau S, Represa A, BenAri Y, Charriaut-Marlangue C: Inflammatory responses in the cerebral cortex after ischemia in the P7 neonatal rat. Stroke 1999. 30:1916-1923, discussion 1923-1924.

46 Lorant DE, Li W, Tabatabaei N, Garver MK Albertine $\mathrm{KH}$ : P-selectin expression by endothelial cells is decreased in neonatal rats and human premature infants. Blood 1999; 94:600-609.

47 Tcharmtchi MH, Smith CW, Mariscalco MM: Neonatal neutrophil interaction with P-selectin: contribution of P-selectin glycoprotein ligand-1 and sialic acid. J Leukoc Biol 2000;67:73-80.

48 Asahi M, Asahi K, Jung JC, del Zoppo GJ, Fini ME, Lo EH: Role for matrix metalloproteinase 9 after focal cerebral ischemia: effects of gene knockout and enzyme inhibition with BB-94. J Cereb Blood Flow Metab 2000; 20:1681-1689.

49 Lee SR, Kim HY, Rogowska J, Zhao BQ, Bhide P, Parent JM, Lo EH: Involvement of matrix metalloproteinase in neuroblast cell migration from the subventricular zone af ter stroke. J Neurosci 2006;26:3491-3495.

50 Wang X, Lee SR, Arai K, Tsuji K, Rebeck GW, Lo EH: Lipoprotein receptor-mediated induction of matrix metalloproteinase by tissue plasminogen activator. Nat Med 2003;9: 1313-1317.

-51 Cunningham LA, Wetzel M, Rosenberg GA: Multiple roles for MMPs and TIMPs in cerebral ischemia. Glia 2005;50:329-339.

52 Fernandez-Patron C, Zouki C, Whittal R, Chan JS, Davidge ST, Filep JG: Matrix metalloproteinases regulate neutrophil-endothelial cell adhesion through generation of endothelin-1 [1-32]. FASEB J 2001;15:22302240 .

53 Dragun P, Makarewicz D, Wojcik L, ZiemkaNalecz M, Slomka M, Zalewska T: Matrix metaloproteinases activity during the evolution of hypoxic-ischemic brain damage in the immature rat. The effect of 1-methylnicotinamide (MNA). J Physiol Pharmacol 2008;59:441-455.

54 Leonardo CC, Eakin AK, Ajmo JM, Collier LA, Pennypacker KR, Strongin AY, Gottschall PE: Delayed administration of a matrix metalloproteinase inhibitor limits progressive brain injury after hypoxia-ischemia in the neonatal rat. J Neuroinflammation 2008;5:34.

55 Komotar RJ, Kim GH, Otten ML, Hassid B, Mocco J, Sughrue ME, Starke RM, Mack WJ Ducruet AF, Merkow MB, Garrett MC, Connolly ES: The role of complement in stroke therapy. Adv Exp Med Biol 2008;632: 23-33.

56 Huang J, Kim LJ, Mealey R, Marsh HC Jr, Zhang Y, Tenner AJ, Connolly ES Jr, Pinsky DJ: Neuronal protection in stroke by an sLex-glycosylated complement inhibitory protein. Science 1999;285:595-599.
57 Figueroa E, Gordon LE, Feldhoff PW, Lassiter HA: The administration of cobra venom factor reduces post-ischemic cerebral injury in adult and neonatal rats. Neurosci Lett 2005;380:48-53.

58 Mocco J, Mack WJ, Ducruet AF, Sosunov SA, Sughrue ME, Hassid BG, Nair MN, Laufer I, Komotar RJ, Claire M, Holland H, Pinsky DJ, Connolly ES Jr: Complement component C3 mediates inflammatory injury following focal cerebral ischemia. Circ Res 2006;99:209217.

59 Ten VS, Bradley-Moore M, Gingrich JA, Stark RI, Pinsky DJ: Brain injury and neurofunctional deficit in neonatal mice with hypoxic-ischemic encephalopathy. Behav Brain Res 2003;145:209-219.

60 Cowell RM, Plane JM, Silverstein FS: Complement activation contributes to hypoxicischemic brain injury in neonatal rats. J Neurosci 2003;23:9459-9468.

61 Lassiter HA: The role of complement in neonatal hypoxic-ischemic cerebral injury. Clin Perinatol 2004;31:117-127.

-62 Ten VS, Sosunov SA, Mazer SP, Stark RI, Caspersen C, Sughrue ME, Botto M, Connolly ES Jr, Pinsky DJ: C1q-deficiency is neuroprotective against hypoxic-ischemic brain injury in neonatal mice. Stroke 2005;36: 2244-2250.

63 Lassiter HA, Walz BM, Wilson JL, Jung E, Calisi CR, Goldsmith LJ, Wilson RA, Morgan BP, Feldhoff RC: The administration of complement component C9 enhances the survival of neonatal rats with Escherichia coli sepsis. Pediatr Res 1997;42:128-136.

64 Lassiter HA, Watson SW, Seifring ML, Tanner JE: Complement factor 9 deficiency in serum of human neonates. J Infect Dis 1992; 166:53-57.

65 Kreutzberg GW: Microglia: a sensor for pathological events in the CNS. Trends Neurosci 1996;19:312-318.

66 Raivich G, Bohatschek M, Kloss CU, Werner A, Jones LL, Kreutzberg GW: Neuroglial activation repertoire in the injured brain: graded response, molecular mechanisms and cues to physiological function. Brain Res Brain Res Rev 1999;30:77-105.

67 Jordan J, Segura T, Brea D, Galindo MF, Castillo J: Inflammation as therapeutic objective in stroke. Curr Pharm Des 2008;14:35493564.

68 Li J, Baud O, Vartanian T, Volpe JJ, Rosenberg PA: Peroxynitrite generated by inducible nitric oxide synthase and NADPH oxidase mediates microglial toxicity to oligodendrocytes. Proc Natl Acad Sci USA 2005;102:9936-9941.

69 Flavin MP, Coughlin K, Ho LT: Soluble macrophage factors trigger apoptosis in cultured hippocampal neurons. Neuroscience 1997; 80:437-448. 
70 Lalancette-Hebert M, Gowing G, Simard A, Weng YC, Kriz J: Selective ablation of proliferating microglial cells exacerbates ischemic injury in the brain. J Neurosci 2007;27:25962605.

-71 Imai F, Suzuki H, Oda J, Ninomiya T, Ono K, Sano H, Sawada M: Neuroprotective effect of exogenous microglia in global brain ischemia. J Cereb Blood Flow Metab 2007;27:488-500.

-72 Schroeter M, Jander S, Huitinga I, Witte OW, Stoll G: Phagocytic response in photochemically induced infarction of rat cerebral cortex. The role of resident microglia. Stroke 1997:28:382-386.

-73 Lambertsen KL, Clausen BH, Babcock AA, Gregersen R, Fenger C, Nielsen $\mathrm{HH}$, Haugaard LS, Wirenfeldt M, Nielsen M, Dagnaes-Hansen F, Bluethmann H, Faergeman NJ, Meldgaard M, Deierborg T, Finsen $\mathrm{B}$ : Microglia protect neurons against ischemia by synthesis of tumor necrosis factor. J Neurosci 2009;29:1319-1330.

-74 Monje ML, Toda H, Palmer TD: Inflammatory blockade restores adult hippocampal neurogenesis. Science 2003;302:1760-1765.

-75 Butovsky O, Ziv Y, Schwartz A, Landa G, Talpalar AE, Pluchino S, Martino G, Schwartz M: Microglia activated by IL- 4 or IFN-gamma differentially induce neurogenesis and oligodendrogenesis from adult stem/progenitor cells. Mol Cell Neurosci 2006;31: 149-160.

76 Walton NM, Sutter BM, Laywell ED, Levkoff LH, Kearns SM, Marshall GP 2nd, Scheffler B, Steindler DA: Microglia instruct subventricular zone neurogenesis. Glia 2006;54: 815-825.

-77 Petersen MA, Dailey ME: Diverse microglial motility behaviors during clearance of dead cells in hippocampal slices. Glia 2004;46: 195-206.

78 Kriz J: Inflammation in ischemic brain injury: timing is important. Crit Rev Neurobiol 2006;18:145-157.

-79 Carson MJ, Sutcliffe JG: Balancing function vs self defense: the CNS as an active regulator of immune responses. J Neurosci Res 1999; $55: 1-8$.

-80 McRae A, Gilland E, Bona E, Hagberg H: Microglia activation after neonatal hypoxicischemia. Brain Res Dev Brain Res 1995;84: 245-252.

-81 Ivacko JA, Sun R, Silverstein FS: Hypoxicischemic brain injury induces an acute microglial reaction in perinatal rats. Pediatr Res 1996;39:39-47.

-82 Cowell RM, Xu H, Galasso JM, Silverstein FS: Hypoxic-ischemic injury induces macrophage inflammatory protein-1alpha expression in immature rat brain. Stroke 2002;33: 795-801.

83 Tsuji M, Higuchi Y, Shiraishi K, Kume T, Akaike A, Hattori H: Protective effect of aminoguanidine on hypoxic-ischemic brain damage and temporal profile of brain nitric oxide in neonatal rat. Pediatr Res 2000;47: 79-83.
84 Fox C, Dingman A, Derugin N, Wendland MF, Manabat C, Ji S, Ferriero DM, Vexler ZS: Minocycline confers early but transient protection in the immature brain following focal cerebral ischemia-reperfusion. J Cereb Blood Flow Metab 2005;25:11381149.

85 Dingman A, Lee SY, Derugin N, Wendland MF, Vexler ZS: Aminoguanidine inhibits caspase- 3 and calpain activation without affecting microglial activation following neonatal transient ischemia. J Neurochem 2006 96:1467-1479.

86 Denker S, Ji S, Lee SY, Dingman A, Derugin $\mathrm{N}$, Wendland M, Vexler ZS: Macrophages are comprised of resident brain microglia not infiltrating peripheral monocytes acutely after neonatal stroke. J Neurochem 2007;100:893904.

87 Santambrogio L, Belyanskaya SL, Fischer FR, Cipriani B, Brosnan CF, Ricciardi-Castagnoli P, Stern LJ, Strominger JL, Riese R: Developmental plasticity of CNS microglia. Proc Natl Acad Sci USA 2001;98:62956300.

88 Carson MJ, Reilly CR, Sutcliffe JG, Lo D: Mature microglia resemble immature antigenpresenting cells. Glia 1998;22:72-85.

89 Hagberg H, Gilland E, Bona E, Hanson LA, Hahin-Zoric $M$, Blennow $M$, Holst $M$, McRae A, Soder O: Enhanced expression of interleukin (IL)-1 and IL-6 messenger RNA and bioactive protein after hypoxia-ischemia in neonatal rats. Pediatr Res 1996;40: 603-609.

-90 Hedtjarn M, Leverin AL, Eriksson K, Blomgren K, Mallard C, Hagberg H: Interleukin-18 involvement in hypoxic-ischemic brain injury. J Neurosci 2002;22:5910-5919.

91 Yrjanheikki J, Keinanen R, Pellikka M, Hokfelt T, Koistinaho J: Tetracyclines inhibit microglial activation and are neuroprotective in global brain ischemia. Proc Natl Acad Sci USA 1998;95:15769-15774.

92 Tikka T, Fiebich BL, Goldsteins G, Keinanen R, Koistinaho J: Minocycline, a tetracycline derivative, is neuroprotective against excitotoxicity by inhibiting activation and proliferation of microglia. J Neurosci 2001;21: 2580-2588.

93 Arvin KL, Han BH, Du Y, Lin SZ, Paul SM, Holtzman DM: Minocycline markedly protects the neonatal brain against hypoxicischemic injury. Ann Neurol 2002;52:5461.

94 Tsuji M, Wilson MA, Lange MS, Johnston MV: Minocycline worsens hypoxic-ischemic brain injury in a neonatal mouse model. Exp Neurol 2004;189:58-65.

$\$ 95$ Dommergues MA, Plaisant F, Verney C, Gressens P: Early microglial activation following neonatal excitotoxic brain damage in mice: a potential target for neuroprotection. Neuroscience 2003;121:619-628.
96 van den Tweel ER, van Bel F, Kavelaars A, Peeters-Scholte CM, Haumann J, Nijboer CH, Heijnen CJ, Groenendaal F: Long-term neuroprotection with 2-iminobiotin, an inhibitor of neuronal and inducible nitric oxide synthase, after cerebral hypoxia-ischemia in neonatal rats. J Cereb Blood Flow Metab 2005;25:67-74.

$\$ 97$ Festoff BW, Ameenuddin S, Arnold PM, Wong A, Santacruz KS, Citron BA: Minocycline neuroprotects, reduces microgliosis, and inhibits caspase protease expression early after spinal cord injury. J Neurochem 2006;97:1314-1326.

-98 Strbian D, Karjalainen-Lindsberg ML, Tatlisumak T, Lindsberg PJ: Cerebral mast cells regulate early ischemic brain swelling and neutrophil accumulation. J Cereb Blood Flow Metab 2006;26:605-612.

-99 Strbian D, Karjalainen-Lindsberg ML, Kovanen PT, Tatlisumak T, Lindsberg PJ: Mast cell stabilization reduces hemorrhage formation and mortality after administration of thrombolytics in experimental ischemic stroke. Circulation 2007;116:411-418.

100 Jin Y, Silverman AJ, Vannucci SJ: Mast cell stabilization limits hypoxic-ischemic brain damage in the immature rat. Dev Neurosci 2007;29:373-384.

101 Biran V, Cochois V, Karroubi A, Arrang JM, Charriaut-Marlangue C, Heron A: Stroke induces histamine accumulation and mast cell degranulation in the neonatal rat brain. Brain Pathol 2008;18:1-9.

102 Hedtjarn M, Mallard C, Hagberg H: Inflammatory gene profiling in the developing mouse brain after hypoxia-ischemia. J Cereb Blood Flow Metab 2004;24:13331351.

103 Catania A, Lipton JM: Peptide modulation of fever and inflammation within the brain. Ann NY Acad Sci 1998;856:62-68.

104 Dong Y, Benveniste EN: Immune function of astrocytes. Glia 2001;36:180-190.

105 Swanson RA, Farrell K, Stein BA: Astrocyte energetics, function, and death under conditions of incomplete ischemia: a mechanism of glial death in the penumbra. Glia 1997;21:142-153.

106 Saas P, Boucraut J, Walker PR, Quiquerez AL, Billot M, Desplat-Jego S, Chicheportiche Y, Dietrich PY: Tweak stimulation of astrocytes and the proinflammatory consequences. Glia 2000;32:102-107.

107 Tang Y, Xu H, Du X, Lit L, Walker W, Lu A, Ran R, Gregg JP, Reilly M, Pancioli A, Khoury JC, Sauerbeck LR, Carrozzella JA, Spilker J, Clark J, Wagner KR, Jauch EC, Chang DJ, Verro P, Broderick JP, Sharp FR: Gene expression in blood changes rapidly in neutrophils and monocytes after ischemic stroke in humans: a microarray study. J Cereb Blood Flow Metab 2006;26:10891102.

108 Emsley HC, Hopkins SJ: Acute ischaemic stroke and infection: recent and emerging concepts. Lancet Neurol 2008;7:341-353. 
109 Grether JK, Nelson KB: Maternal infection and cerebral palsy in infants of normal birth weight. JAMA 1997;278:207-211.

110 Foster-Barber A, Ferriero DM: Neonatal encephalopathy in the term infant: neuroimaging and inflammatory cytokines. Ment Retard Dev Disabil Res Rev 2002;8: 20-24.

-111 Bartha AI, Foster-Barber A, Miller SP, Vigneron DB, Glidden DV, Barkovich AJ, Ferriero DM: Neonatal encephalopathy: association of cytokines with MR spectroscopy and outcome. Pediatr Res 2004;56:960966.

-112 Touzani O, Boutin H, LeFeuvre R, Parker L, Miller A, Luheshi G, Rothwell N: Interleukin-1 influences ischemic brain damage in the mouse independently of the interleukin-1 type I receptor. J Neurosci 2002;22: $38-43$.

- 113 Yamasaki Y, Matsuura N, Shozuhara H, Onodera H, Itoyama Y, Kogure K: Interleukin-1 as a pathogenetic mediator of ischemic brain damage in rats. Stroke 1995;26: 676-680, discussion 681.

114 Boutin H, LeFeuvre RA, Horai R, Asano M, Iwakura Y, Rothwell NJ: Role of IL-1alpha and IL-1beta in ischemic brain damage. J Neurosci 2001;21:5528-5534.

115 Relton JK, Martin D, Thompson RC, Russell DA: Peripheral administration of interleukin-1 receptor antagonist inhibits brain damage after focal cerebral ischemia in the rat. Exp Neurol 1996;138:206-213.

-116 Betz AL, Yang GY, Davidson BL: Attenuation of stroke size in rats using an adenoviral vector to induce overexpression of interleukin-1 receptor antagonist in brain. J Cereb Blood Flow Metab 1995;15:547-551.

- 117 Lazovic J, Basu A, Lin HW, Rothstein RP, Krady JK, Smith MB, Levison SW: Neuroinflammation and both cytotoxic and vasogenic edema are reduced in interleukin-1 type 1 receptor-deficient mice conferring neuroprotection. Stroke 2005;36:22262231.

-118 Abulafia DP, de Rivero Vaccari JP, Lozano JD, Lotocki G, Keane RW, Dietrich WD: Inhibition of the inflammasome complex reduces the inflammatory response after thromboembolic stroke in mice. J Cereb Blood Flow Metab 2009;29:534-544.

-119 Doverhag C, Keller M, Karlsson A, Hedtjarn M, Nilsson U, Kapeller E, Sarkozy G, Klimaschewski L, Humpel C, Hagberg H, Simbruner G, Gressens P, Savman K: Pharmacological and genetic inhibition of NADPH oxidase does not reduce brain damage in different models of perinatal brain injury in newborn mice. Neurobiol Dis 2008;31:133-144.

120 Hedtjarn M, Mallard C, Iwakura Y, Hagberg H: Combined deficiency of IL-1beta18, but not IL-1alphabeta, reduces susceptibility to hypoxia-ischemia in the immature brain. Dev Neurosci 2005;27:143-148.
121 Girard S, Kadhim H, Larouche A, Roy M, Gobeil F, Sebire G: Pro-inflammatory disequilibrium of the IL-1 beta/IL-1ra ratio in an experimental model of perinatal brain damages induced by lipopolysaccharide and hypoxia-ischemia. Cytokine 2008;43: 54-62.

122 Ohtaki H, Yin L, Nakamachi T, Dohi K, Kudo Y, Makino R, Shioda S: Expression of tumor necrosis factor alpha in nerve fibers and oligodendrocytes after transient focal ischemia in mice. Neurosci Lett 2004;368: $162-166$.

123 Liu T, Clark RK, McDonnell PC, Young PR, White RF, Barone FC, Feuerstein GZ: Tumor necrosis factor-alpha expression in ischemic neurons. Stroke 1994;25:1481-1488.

124 Feuerstein G, Wang X, Barone FC: Cytokines in brain ischemia - the role of TNF alpha. Cell Mol Neurobiol 1998;18:695701 .

125 Barone FC, Arvin B, White RF, Miller A Webb CL, Willette RN, Lysko PG, Feuerstein GZ: Tumor necrosis factor-alpha. A mediator of focal ischemic brain injury. Stroke 1997;28:1233-1244.

126 Bruce AJ, Boling W, Kindy MS, Peschon J, Kraemer PJ, Carpenter MK, Holtsberg FW, Mattson MP: Altered neuronal and microglial responses to excitotoxic and ischemic brain injury in mice lacking TNF receptors. Nat Med 1996;2:788-794

127 Lovering F, Zhang Y: Therapeutic potential of TACE inhibitors in stroke. Curr Drug Targets CNS Neurol Disord 2005;4:161168

128 Hallenbeck JM: The many faces of tumor necrosis factor in stroke. Nat Med 2002;8. 1363-1368.

129 Graham EM, Sheldon RA, Flock DL, Ferriero DM, Martin LJ, O'Riordan DP, Northington FJ: Neonatal mice lacking functional Fas death receptors are resistant to hypoxic-ischemic brain injury. Neurobiol Dis 2004;17:89-98.

130 Clark WM, Rinker LG, Lessov NS, Hazel K, Hill JK, Stenzel-Poore M, Eckenstein F: Lack of interleukin- 6 expression is not protective against focal central nervous system ischemia. Stroke 2000;31:1715-1720.

-131 Herrmann O, Tarabin V, Suzuki S, Attigah N, Coserea I, Schneider A, Vogel J, Prinz S, Schwab S, Monyer H, Brombacher F, Schwaninger M: Regulation of body temperature and neuroprotection by endogenous interleukin-6 in cerebral ischemia. J Cereb Blood Flow Metab 2003;23:406415.

132 Smith CJ, Emsley HC, Gavin CM, Georgiou RF, Vail A, Barberan EM, del Zoppo GJ, Hallenbeck JM, Rothwell NJ, Hopkins SJ, Tyrrell PJ: Peak plasma interleukin-6 and other peripheral markers of inflammation in the first week of ischaemic stroke correlate with brain infarct volume, stroke severity and long-term outcome. BMC Neurol 2004;4:2.
133 Krady JK, Lin HW, Liberto CM, Basu A, Kremlev SG, Levison SW: Ciliary neurotrophic factor and interleukin-6 differentially activate microglia. J Neurosci Res 2008;86:1538-1547.

134 Szaflarski J, Burtrum D, Silverstein FS: Cerebral hypoxia-ischemia stimulates cytokine gene expression in perinatal rats. Stroke 1995;26:1093-1100.

135 Wheeler RD, Boutin H, Touzani O, Luheshi GN, Takeda K, Rothwell NJ: No role for interleukin-18 in acute murine stroke-induced brain injury. J Cereb Blood Flow Metab 2003;23:531-535.

136 Qiu L, Zhu C, Wang X, Xu F, Eriksson PS, Nilsson M, Cooper-Kuhn CM, Kuhn HG, Blomgren $\mathrm{K}$ : Less neurogenesis and inflammation in the immature than in the juvenile brain after cerebral hypoxia-ischemia. J Cereb Blood Flow Metab 2007;27: 785-794.

137 Fontaine RH, Cases O, Lelievre V, Mesples B, Renauld JC, Loron G, Degos V, Dournaud P, Baud O, Gressens P: IL-9/IL-9 receptor signaling selectively protects cortical neurons against developmental apoptosis. Cell Death Differ 2008;15:1542-1552.

138 Dommergues MA, Patkai J, Renauld JC, Evrard P, Gressens P: Proinflammatory cytokines and interleukin-9 exacerbate excitotoxic lesions of the newborn murine neopallium. Ann Neurol 2000;47:54-63.

139 Patkai J, Mesples B, Dommergues MA, Fromont G, Thornton EM, Renauld JC, Evrard P, Gressens P: Deleterious effects of IL9-activated mast cells and neuroprotection by antihistamine drugs in the developing mouse brain. Pediatr Res 2001;50:222230.

140 Mesples B, Plaisant F, Gressens P: Effects of interleukin-10 on neonatal excitotoxic brain lesions in mice. Brain Res Dev Brain Res 2003;141:25-32.

141 Dietrich WD, Busto R, Bethea JR: Postischemic hypothermia and IL-10 treatment provide long-lasting neuroprotection of CA1 hippocampus following transient global ischemia in rats. Exp Neurol 1999; 158:444-450.

142 Ooboshi H, Ibayashi S, Shichita T, Kumai Y, Takada J, Ago T, Arakawa S, Sugimori H, Kamouchi M, Kitazono T, Iida M: Postischemic gene transfer of interleukin-10 protects against both focal and global brain ischemia. Circulation 2005;111:913-919.

143 Zhao W, Xie W, Xiao Q, Beers DR, Appel $\mathrm{SH}$ : Protective effects of an anti-inflammatory cytokine, interleukin-4, on motoneuron toxicity induced by activated microglia. J Neurochem 2006;99:1176-1187.

144 Gerard C, Rollins BJ: Chemokines and disease. Nat Immunol 2001;2:108-115. 
145 Huang DR, Wang J, Kivisakk P, Rollins BJ, Ransohoff RM: Absence of monocyte chemoattractant protein 1 in mice leads to decreased local macrophage recruitment and antigen-specific $\mathrm{T}$ helper cell type $1 \mathrm{im}$ mune response in experimental autoimmune encephalomyelitis. J Exp Med 2001; 193:713-726.

146 Huang D, Tani M, Wang J, Han Y, He TT, Weaver J, Charo IF, Tuohy VK, Rollins BJ, Ransohoff RM: Pertussis toxin-induced reversible encephalopathy dependent on monocyte chemoattractant protein-1 overexpression in mice. J Neurosci 2002;22: 10633-10642.

- 147 Kumai Y, Ooboshi H, Takada J, Kamouchi M, Kitazono T, Egashira K, Ibayashi S, Iida M: Antimonocyte chemoattractant protein-1 gene therapy protects against focal brain ischemia in hypertensive rats. J Cereb Blood Flow Metab 2004;24:1359-1368.

148 Hughes PM, Allegrini PR, Rudin M, Perry VH, Mir AK, Wiessner C: Monocyte chemoattractant protein-1 deficiency is protective in a murine stroke model. J Cereb Blood Flow Metab 2002;22:308-317.

149 Chen Y, Hallenbeck JM, Ruetzler C, Bol D, Thomas K, Berman NE, Vogel SN: Overexpression of monocyte chemoat tractant protein 1 in the brain exacerbates ischemic brain injury and is associated with recruitment of inflammatory cells. J Cereb Blood Flow Metab 2003;23:748-755.

-150 Xu H, Barks JD, Schielke GP, Silverstein FS: Attenuation of hypoxia-ischemia-induced monocyte chemoattractant protein-1 expression in brain of neonatal mice deficient in interleukin-1 converting enzyme. Brain Res Mol Brain Res 2001;90:57-67.

151 Galasso JM, Miller MJ, Cowell RM, Harrison JK, Warren JS, Silverstein FS: Acute excitotoxic injury induces expression of monocyte chemoattractant protein-1 and its receptor, CCR2, in neonatal rat brain. Exp Neurol 2000;165:295-305.

-152 Nishi T, Maier CM, Hayashi T, Saito A, Chan PH: Superoxide dismutase 1 overexpression reduces MCP-1 and MIP-1alpha expression after transient focal cerebral ischemia. J Cereb Blood Flow Metab 2005; 25:1312-1324.

153 McMahon EJ, Cook DN, Suzuki K, Matsushima GK: Absence of macrophage-inflammatory protein-1alpha delays central nervous system demyelination in the presence of an intact blood-brain barrier. J Immunol 2001;167:2964-2971.

154 Belperio JA, Keane MP, Arenberg DA, Addison CL, Ehlert JE, Burdick MD, Strieter RM: CXC chemokines in angiogenesis. J Leukoc Biol 2000;68:1-8.

155 Veldhuis WB, Floris S, van der Meide PH, Vos IM, de Vries HE, Dijkstra CD, Bar PR, Nicolay K: Interferon-beta prevents cytokine-induced neutrophil infiltration and attenuates blood-brain barrier disruption. J Cereb Blood Flow Metab 2003;23:1060-1069.
156 Yamasaki Y, Matsuo Y, Matsuura N, Onodera H, Itoyama Y, Kogure K: Transient increase of cytokine-induced neutrophil chemoattractant, a member of the interleukin-8 family, in ischemic brain areas after focal ischemia in rats. Stroke 1995;26:318322, discussion 322-323.

157 Dingman A, Derugin N, Ji S, Wendland M, Bollen A, Vexler ZS: Increased levels of cytokine-induced neutrophil chemoattractant protein1 (CINC-1) acutely after neonatal focal ischemia-reperfusion are not associated with neutrophil accumulation. Soc Neurosci 2004;A472.

158 Hill WD, Hess DC, Martin-Studdard A, Carothers JJ, Zheng J, Hale D, Maeda M, Fagan SC, Carroll JE, Conway SJ: SDF-1 (CXCL12) is upregulated in the ischemic penumbra following stroke: association with bone marrow cell homing to injury. J Neuropathol Exp Neurol 2004;63:84-96.

159 Wang L, Li Y, Chen X, Chen J, Gautam SC, Xu Y, Chopp M: MCP-1, MIP-1, IL-8 and ischemic cerebral tissue enhance human bone marrow stromal cell migration in interface culture. Hematology 2002;7:113117.

160 Miller JT, Bartley JH, Wimborne HJ, Walker AL, Hess DC, Hill WD, Carroll JE: The neuroblast and angioblast chemotaxic factor SDF-1 (CXCL12) expression is briefly upregulated by reactive astrocytes in brain following neonatal hypoxic-ischemic injury. BMC Neurosci 2005;6:63.

161 Chan PH: Reactive oxygen radicals in signaling and damage in the ischemic brain. Cereb Blood Flow Metab 2001;21:2-14.

162 Fullerton HJ, Ditelberg JS, Chen SF, Sarco DP, Chan PH, Epstein CJ, Ferriero DM: Copper/zinc superoxide dismutase transgenic brain accumulates hydrogen peroxide after perinatal hypoxia ischemia. Ann Neurol 1998;44:357-364.

163 Sheldon RA, Jiang X, Francisco C, Christen S, Vexler ZS, Tauber MG, Ferriero DM: Manipulation of antioxidant pathways in neonatal murine brain. Pediatr Res 2004;56: 656-662.

164 Lafemina MJ, Sheldon RA, Ferriero DM: Acute hypoxia-ischemia results in hydrogen peroxide accumulation in neonatal but not adult mouse brain. Pediatr Res 2006;59: 680-683.

165 Sheldon RA, Christen S, Ferriero DM: Genetic and pharmacologic manipulation of oxidative stress after neonatal hypoxiaischemia. Int J Dev Neurosci 2008;26:8792.

166 Walder CE, Green SP, Darbonne WC, Mathias J, Rae J, Dinauer MC, Curnutte JT, Thomas GR: Ischemic stroke injury is reduced in mice lacking a functional NADPH oxidase. Stroke 1997;28:2252-2258.

167 Tang XN, Cairns B, Cairns N, Yenari MA Apocynin improves outcome in experimental stroke with a narrow dose range. Neuroscience 2008;154:556-562.
168 Lipton SA: Neuronal protection and destruction by NO. Cell Death Differ 1999;6: 943-951.

169 Murphy S: Production of nitric oxide by glial cells: regulation and potential roles in the CNS. Glia 2000;29:1-13.

170 Bonfoco E, Krainc D, Ankarcrona M, Nicotera P, Lipton SA: Apoptosis and necrosis: two distinct events induced, respectively, by mild and intense insults with N-methylD-aspartate or nitric oxide/superoxide in cortical cell cultures. Proc Natl Acad Sci USA 1995;92:7162-7166.

- 171 Nogawa S, Forster C, Zhang F, Nagayama M, Ross ME, Iadecola C: Interaction between inducible nitric oxide synthase and cyclooxygenase-2 after cerebral ischemia. Proc Natl Acad Sci USA 1998;95:10966-10971.

172 Iadecola C, Zhang F, Casey R, Nagayama M, Ross ME: Delayed reduction of ischemic brain injury and neurological deficits in mice lacking the inducible nitric oxide synthase gene. J Neurosci 1997;17:9157-9164.

173 Iadecola C, Zhang F, Xu X: Inhibition of inducible nitric oxide synthase ameliorates cerebral ischemic damage. Am J Physiol 1995;268:R286-R292.

174 Peeters-Scholte C, Koster J, Veldhuis W, van den Tweel E, Zhu C, Kops N, Blomgren $\mathrm{K}$, Bar D, van Buul-Offers S, Hagberg H, Nicolay K, van Bel F, Groenendaal F: Neuroprotection by selective nitric oxide synthase inhibition at $24 \mathrm{~h}$ after perinatal hypoxia-ischemia. Stroke 2002;33:23042310.

175 Sharp FR, Lu A, Tang Y, Millhorn DE: Multiple molecular penumbras after focal cerebral ischemia. J Cereb Blood Flow Metab 2000;20:1011-1032.

176 Hedtjarn M, Mallard C, Eklind S, Gustafson-Brywe K, Hagberg H: Global gene expression in the immature brain after hypoxia-ischemia. J Cereb Blood Flow Metab 2004;24:1317-1332.

177 Baeuerle PA, Henkel T: Function and activation of NF-kappa B in the immune system. Annu Rev Immunol 1994;12:141-179.

178 Herrmann O, Baumann B, de Lorenzi R, Muhammad S, Zhang W, Kleesiek J, Malfertheiner M, Kohrmann M, Potrovita I, Maegele I, Beyer C, Burke JR, Hasan MT, Bujard $\mathrm{H}$, Wirth T, Pasparakis M, Schwaninger M: IKK mediates ischemia-induced neuronal death. Nat Med 2005;11:1322-1329.

179 Zheng Z, Yenari MA: Post-ischemic inflammation: molecular mechanisms and therapeutic implications. Neurol Res 2004; 26:884-892.

180 Schneider A, Martin-Villalba A, Weih F, Vogel J, Wirth T, Schwaninger M: NF-kap$\mathrm{paB}$ is activated and promotes cell death in focal cerebral ischemia. Nat Med 1999;5: 554-559.

181 Zheng Z, Kim JY, Ma H, Lee JE, Yenari MA: Anti-inflammatory effects of the $70 \mathrm{kDa}$ heat shock protein in experimental stroke. J Cereb Blood Flow Metab 2008;28:53-63. 
182 Cechetto DF: Role of nuclear factor kappa B in neuropathological mechanisms. Prog Brain Res 2001;132:391-404.

- 183 Hill WD, Hess DC, Carroll JE, Wakade CG, Howard EF, Chen Q, Cheng C, MartinStuddard A, Waller JL, Beswick RA: The NF-kappaB inhibitor diethyldithiocarbamate (DDTC) increases brain cell death in a transient middle cerebral artery occlusion model of ischemia. Brain Res Bull 2001;55: 375-386.

184 Nijboer CH, Heijnen CJ, Groenendaal F, May MJ, van Bel F, Kavelaars A: Strong neuroprotection by inhibition of NF-kappaB after neonatal hypoxia-ischemia involves apoptotic mechanisms but is independent of cytokines. Stroke 2008;39:2129-2137.

- 185 Nijboer CH, Heijnen CJ, Groenendaal F, May MJ, van Bel F, Kavelaars A: A dual role of the NF-kappaB pathway in neonatal hypoxic-ischemic brain damage. Stroke 2008; 39:2578-2586.

- 186 van den Tweel ER, Kavelaars A, Lombardi MS, Groenendaal F, May M, Heijnen CJ, van Bel F: Selective inhibition of nuclear factor-kappaB activation after hypoxia/ ischemia in neonatal rats is not neuroprotective. Pediatr Res 2006;59:232-236.

- 187 Fabian RH, Perez-Polo JR, Kent TA: A decoy oligonucleotide inhibiting nuclear factorkappaB binding to the IgGkappaB consensus site reduces cerebral injury and apoptosis in neonatal hypoxic-ischemic encephalopathy. J Neurosci Res 2007;85:1420-1426.

188 Kyriakis JM, Avruch J: Mammalian mitogen-activated protein kinase signal transduction pathways activated by stress and inflammation. Physiol Rev 2001;81:807-869.

189 Saccani S, Pantano S, Natoli G: p38-Dependent marking of inflammatory genes for increased NF-kappa B recruitment. Nat Immunol 2002;3:69-75.

190 Sugino T, Nozaki K, Takagi Y, Hattori I, Hashimoto N, Moriguchi T, Nishida E: Activation of mitogen-activated protein kinases after transient forebrain ischemia in gerbil hippocampus. J Neurosci 2000;20: 4506-4514.

191 Walton KM, DiRocco R, Bartlett BA, Koury E, Marcy VR, Jarvis B, Schaefer EM, Bhat RV: Activation of p38MAPK in microglia after ischemia. J Neurochem 1998;70:1764-1767.

192 Mehta SL, Manhas N, Raghubir R: Molecular targets in cerebral ischemia for developing novel therapeutics. Brain Res Rev 2007; 54:34-66.

193 Hee Han B, Choi J, Holtzman DM: Evidence that p38 mitogen-activated protein kinase contributes to neonatal hypoxicischemic brain injury. Dev Neurosci 2002; 24:405-410.

-194 Kuan CY, Whitmarsh AJ, Yang DD, Liao G, Schloemer AJ, Dong C, Bao J, Banasiak KJ, Haddad GG, Flavell RA, Davis RJ, Rakic P: A critical role of neural-specific JNK3 for ischemic apoptosis. Proc Natl Acad Sci USA 2003;100:15184-15189.
195 Pirianov G, Brywe KG, Mallard C, Edwards AD, Flavell RA, Hagberg H, Mehmet H: Deletion of the c-Jun $\mathrm{N}$-terminal kinase 3 gene protects neonatal mice against cerebral hypoxic-ischaemic injury. J Cereb Blood Flow Metab 2007;27:1022-1032.

196 Hagberg H, Wilson MA, Matsushita H, Zhu C, Lange M, Gustavsson M, Poitras MF, Dawson TM, Dawson VL, Northington F, Johnston MV: PARP-1 gene disruption in mice preferentially protects males from perinatal brain injury. J Neurochem 2004; 90:1068-1075.

197 Renolleau S, Fau S, Goyenvalle C, Joly LM, Chauvier D, Jacotot E, Mariani J, Charriaut-Marlangue C: Specific caspase inhibitor Q-VD-OPh prevents neonatal stroke in P7 rat: a role for gender. J Neurochem 2007; 100:1062-1071.

198 Nijboer CH, Groenendaal F, Kavelaars A, Hagberg HH, van Bel F, Heijnen CJ: Gender-specific neuroprotection by 2 -iminobiotin after hypoxia-ischemia in the neonatal rat via a nitric oxide independent pathway. J Cereb Blood Flow Metab 2007; 27:282-292.

199 Han HS, Yenari MA: Protective mechanisms of hypothermia in focal cerebral ischemia; in Tisherman SA, Sterz F (eds): Therapeutic Hypothermia. New York, Springer, 2005, pp 25-41.

200 Liu Y, Barks JD, Xu G, Silverstein FS: Topiramate extends the therapeutic window for hypothermia-mediated neuroprotection after stroke in neonatal rats. Stroke 2004; 35:1460-1465.

201 Parent JM, Vexler ZS, Gong C, Derugin N, Ferriero DM: Rat forebrain neurogenesis and striatal neuron replacement after focal stroke. Ann Neurol 2002;52:802-813.

202 Lindvall O, Kokaia Z: Recovery and rehabilitation in stroke: stem cells. Stroke 2004; 35:2691-2694.

203 Chang YS, Mu D, Wendland M, Sheldon RA, Vexler ZS, McQuillen PS, Ferriero DM: Erythropoietin improves functional and histological outcome in neonatal stroke. Pediatr Res 2005;58:106-111.

204 Plane JM, Liu R, Wang TW, Silverstein FS, Parent JM: Neonatal hypoxic-ischemic injury increases forebrain subventricular zone neurogenesis in the mouse. Neurobiol Dis 2004;16:585-595.

205 Arvidsson A, Collin T, Kirik D, Kokaia Z, Lindvall O: Neuronal replacement from endogenous precursors in the adult brain after stroke. Nat Med 2002;8:963-970.

206 Battista D, Ferrari CC, Gage FH, Pitossi FJ: Neurogenic niche modulation by activated microglia: transforming growth factor beta increases neurogenesis in the adult dentate gyrus. Eur J Neurosci 2006;23:83-93.
207 Iosif RE, Ekdahl CT, Ahlenius H, Pronk CJ, Bonde S, Kokaia Z, Jacobsen SE, Lindvall O: Tumor necrosis factor receptor 1 is a negative regulator of progenitor proliferation in adult hippocampal neurogenesis. J Neurosci 2006;26:9703-9712.

208 Schwartz M, Butovsky O, Bruck W, Hanisch UK: Microglial phenotype: is the commitment reversible? Trends Neurosci 2006;29: $68-74$.

209 Li Y, Chen J, Zhang CL, Wang L, Lu D, Katakowski M, Gao Q, Shen LH, Zhang J, Lu M, Chopp M: Gliosis and brain remodeling after treatment of stroke in rats with marrow stromal cells. Glia 2005;49:407417.

210 Ohab JJ, Fleming S, Blesch A, Carmichael ST: A neurovascular niche for neurogenesis after stroke. J Neurosci 2006;26:1300713016.

211 Thored P, Heldmann U, Gomes-Leal W, Gisler R, Darsalia V, Taneera J, Nygren JM, Jacobsen SE, Ekdahl CT, Kokaia Z, Lindvall O: Long-term accumulation of microglia with proneurogenic phenotype concomitant with persistent neurogenesis in adult subventricular zone after stroke. Glia 2009; 57:835-849.

212 Libert S, Cohen D, Guarente L: Neurogenesis directed by SIRT1. Nat Cell Biol 2008; 10:373-374.

213 Felling RJ, Snyder MJ, Romanko MJ, Rothstein RP, Ziegler AN, Yang Z, Givogri MI, Bongarzone ER, Levison SW: Neural stem/ progenitor cells participate in the regenerative response to perinatal hypoxia/ischemia. J Neurosci 2006;26:4359-4369.

214 Wang X, Hagberg H, Nie C, Zhu C, Ikeda T, Mallard C: Dual role of intrauterine immune challenge on neonatal and adult brain vulnerability to hypoxia-ischemia. J Neuropathol Exp Neurol 2007;66:552561.

215 Sifringer M, Genz K, Brait D, Brehmer F, Löber R, Weichelt U, Kaindl AM, Gerstner B, Felderhoff-Mueser U: Erythropoietin attenuates hyperoxia-induced cell death by modulation of inflammatory mediators and matrix metalloproteinases. Dev Neurosci 2009;31:394-402.

216 Gonzalez FF, Abel R, Almli CR, Mu D, Wendland M, Ferriero DM: Erythropoietin sustains cognitive function and brain volume after neonatal stroke. Dev Neurosci 2009;31:403-411.

217 Svedin P, Hagberg H, Mallard C: Expression of MMP-12 after neonatal hypoxicischemic brain injury in mice. Dev Neurosci 2009;31:427-436.

-218 Carlsson Y, Leverin AL, Hedtjärn M, Wang X, Mallard C, Hagberg H: Role of MLK inhibition in neonatal hypoxia-ischemia. Dev Neurosci 2009;31:420-426. 